\title{
Antioxidant Redox Sensors Based on DNA Modified Carbon Screen-Printed Electrodes
}

\author{
Jifeng Liu,† Bin Su,` Grégoire Lagger,‡ Philippe Tacchini,‡ and Hubert H. Girault*,† \\ Laboratoire d'Electrochimie Physique et Analytique, Station 6, Ecole Polytechnique Federale de Lausanne, \\ CH-1015, Lausanne, Switzerland, and EDEL Therapeutics SA, PSE-B, EPFL, CH-1015, Lausanne, Switzerland
}

\begin{abstract}
Antioxidant redox sensors based on DNA modified carbon screen-printed electrodes were developed. The carbon ink was doped with $\mathrm{TiO}_{2}$ nanoparticles, onto which doublestrand DNA was adsorbed. A redox mediator, namely, tris$2,2^{\prime}$-bipyridine ruthenium(II) $\left[\mathrm{Ru}(\mathrm{bpy})_{3}{ }^{2+}\right]$ was electrooxidized on the electrode surface to subsequently oxidize both the adsorbed ds-DNA and the antioxidants in solution. The resulting oxidation damage of the adsorbed dsDNA was then detected by square wave voltammetry in a second solution containing only $\mathrm{Ru}(\mathrm{bpy})_{3} \mathrm{Cl}_{2}$ at a low concentration $(\mu \mathrm{M})$. A kinetic model was developed to study the protecting role of antioxidants in aqueous solutions. The electrochemical sensor has been applied to evaluate the redox antioxidant capacity of different molecules.
\end{abstract}

The role of antioxidants (AOs) in life science is of great interest both to the general public and to experts in different disciplines including medicine, nutrition, health, and food science. Indeed, it is of fundamental importance to understand and control the oxidative stress in biological systems. However, oxidative pathways are numerous and many different species can act as antioxidants. We can distinguish the enzymatic antioxidant activity (for example, of superoxide dismutase) from the molecular activity whereby molecules, acting as scavengers, are sacrificially oxidized, for example, by reactive oxygen/nitrogen species (ROS/RNS). Those sacrificial molecules can be either endogenous such as glutathione or exogenous such as ascorbic acid. From a mechanistic viewpoint, molecules can be oxidized either by hydrogen atom acceptors (e.g., ROO• ) or by electron acceptors (e.g., $\mathrm{Fe}^{3+}$ ). To study the antioxidant properties of molecules acting through the radical reaction pathway, many methods have been proposed whereby a radical is thermally or photochemically generated. These methods using absorbance or fluorescent indicators ${ }^{1,2}$ yield different parameters such as, for example, the total radical trapping antioxidant parameter, ${ }^{3}$ the oxygen radical absorbance capacity, ${ }^{4}$ and the

\footnotetext{
* Corresponding author. Tel: +4121 693 3145. Fax: +4121 6933667. E-mail: hubert.girault@epfl.ch.

${ }^{\dagger}$ Ecole Polytechnique Federale de Lausanne.

* EDEL Therapeutics SA.

(1) Huang, D.; Ou, B.; Prior, R. L. J. Agric. Food Chem. 2005, 53, 1841-1856.

(2) Antolovich, M.; Prenzler, P. D.; Patsalides, E.; McDonald, S.; Robards, K. Analyst 2002, 127, 183-198.

(3) Wayner, D. D. M.; Burton, G. W.; Ingold, K. U.; Locke, S. FEBS Lett. 1985, 187, 33-37.

(4) Cao, G. H.; Alessio, H. M.; Cutler, R. G. Free Radical Biol. Med. 1993, 14, 303-311.

2,2-diphenyl-1-picrylhydrazyl radical scavenging capacity. ${ }^{5}$ Alternatively, to study the antioxidant properties of molecules acting through the electron-transfer pathway, some optical methods have been developed such as the trolox equivalent antioxidant capacity ${ }^{6}$ or the ferric ion reducing antioxidant power. ${ }^{7}$ In addition to optical methods, electrochemical sensors have also been designed to measure the redox antioxidant capacities of molecules, for example, by monitoring the oxygen reduction current at a mercury film electrode. ${ }^{8,9}$

In biological conditions, DNA damages caused by ROS or RNS are complex and involve base oxidation, sugar fragmentation, and DNA strand structure changes such as strand breaks, interstrand/ intrastrand cross-links, and DNA-protein cross-links. ${ }^{10}$ DNA oxidation damages appear to be associated with cancer and a number of non-neoplastic pathologies including neurodegenerative, cardiovascular, and autoimmune diseases. ${ }^{10,11}$ Therefore, it is important to study the damaging effects of oxidative stress on DNA and the protective effects of AOs against such damages.

Traditional methods for DNA damage analysis include gel electrophoresis, gas chromatography, and HPLC with mass spectrometry or electrochemical detection. ${ }^{12-17}$ Sensors to study DNA oxidation damage have been developed based on electrochemistry at DNA adsorbed mercury electrodes ${ }^{18-24}$ and layer-by-layer

(5) Blois, M. S. Nature 1958, 181, 1199-1200.

(6) Miller, N. J.; Rice-Evans, C. A.; Davies, M. J.; Gopinathan, V.; Milner, A. Clin. Sci. 1993, 84, 407-412.

(7) Benzie, I. F. F.; Strain, J. J. Anal. Biochem. 1996, 239, 70-76.

(8) Bashkatova, N. V.; Korotkova, E. I.; Karbainov, Y. A.; Yagovkin, A. Y.; Bakibaev, A. A. J. Pharm. Biomed. Anal. 2005, 37, 1143-1147.

(9) Korotkova, E. I.; Karbainov, Y. A.; Shevchuk, A. V. J. Electroanal. Chem. 2002, 518, 56-60.

(10) Evans, M. D.; Cooke, M. S. BioEssays 2004, 26, 533-542.

(11) Harman, D. Proc. Natl. Acad. Sci. U.S.A. 1981, 78, 7124-7128.

(12) Wijeratne, S. S. K.; Abou-Zaid, M. M.; Shahidi, F. J. Agric. Food Chem. 2006 , $54,312-318$.

(13) Wijeratne, S. S. K.; Cuppett, S. L.; Schlegel, V. J. Agric. Food Chem. 2005, 53, 8768-8774.

(14) Aruoma, O. I.; Halliwell, B.; Gajewski, E.; Dizdaroglu, M. J. Biol. Chem. 1989, 264, 20509-20512.

(15) Helbock, H. J.; Beckman, K. B.; Shigenaga, M. K.; Walter, P. B.; Woodall, A. A.; Yeo, H. C.; Ames, B. N. Proc. Natl. Acad. Sci. U.S.A. 1998, 95, 288293

(16) Gabbita, S. P.; Lovell, M. A.; Markesbery, W. R. J. Neurochem. 1998, 71, 2034-2040.

(17) Jenner, A.; England, T. G.; Aruoma, O. I.; Halliwell, B. Biochem. J. 1998 , 331, 365-369.

(18) Fojita, M.; Havran, L.; Palecek, E. Electroanalysis 1997, 9, 1033-1034.

(19) Fojta, M.; Palecek, E. Anal. Chim. Acta 1997, 342, 1-12.

(20) Palecek, E.; Fojta, M.; Tomschik, M.; Wang, J. Biosens. Bioelectron. 1998, 13, 621-628. 
assembled polymer-DNA modified electrodes. ${ }^{25,26}$ In a platform of DNA modified electrodes, an adsorbed DNA layer is used as sensor substrate and chemicals causing DNA damage can be studied including pathogenic organisms, ${ }^{27-30}$ toxicants, ${ }^{24,31-33}$ and AOs. ${ }^{34,35}$

There are two main approaches to oxidize DNA, either by $\mathrm{OH}^{\bullet}$ radicals or by electron acceptors. An easy way to photogenerate $\mathrm{OH} \bullet$ radicals is to carry out photocatalytic reactions on $\mathrm{TiO}_{2}$. DNA fragments and damaged DNA bases have been detected after such a photoinduced degradation. ${ }^{36,37}$ In our group, we have developed a photoelectrochemical method based on the fabrication of $\mathrm{TiO}_{2-}$ coated indium tin oxide (ITO) glass electrodes for studying double-stranded (ds)-DNA photooxidation by UV irradiation in the presence of AOs. ${ }^{38}$ The $\mathrm{TiO}_{2}$ nanocrystalline film was used as a substrate for immobilizing the DNA, as a photocatalyst for the photogeneration of $\mathrm{OH}^{\bullet}$ radicals under UV light to oxidize the surface-bound ds-DNA, and as an electrode to monitor the reduction current of methylene blue, acting as a sensitive redox intercalant to monitor the resulting ds-DNA damage. ${ }^{38}$ In this method, AOs acted as hydrogen donors to scavenge radicals and thereby protecting the adsorbed ds-DNA.

When studying the oxidation of DNA by electron acceptors, metal complexes, such as tris-2,2'-bipyridine ruthenium(III) $\left[\mathrm{Ru}(\mathrm{bpy}){ }_{3}{ }^{3+}\right]$ have proved to be efficient oxidants through electrontransfer reactions between $\mathrm{Ru}(\mathrm{bpy})_{3}{ }^{3+}$ and guanine $\mathrm{e}^{39}$ or adenine. ${ }^{40,41}$ In the present paper, we develop AO redox sensors based on ds-DNA modified screen-printed electrodes (SPEs) composed of graphite flakes and $\mathrm{TiO}_{2}$ aggregates. An oxidizing mediator, namely, $\mathrm{Ru}(\mathrm{bpy}) 3^{3+}$, is electrogenerated on the carbon in the presence of AOs in the solution and is used to oxidize the ds-DNA adsorbed on the $\mathrm{TiO}_{2}$ particles. The same electrode is then used to monitor the ds-DNA damage by square wave

(21) Fojta, M.; Kubicarova, T.; Palecek, E. Biosens. Bioelectron. 2000, 15, 107115.

(22) Palecek, E.; Fojta, M. Anal. Chem. 2001, 73, 74A-83A.

(23) Fojta, M.; Havran, L.; Kubicarova, T.; Palecek, E. Bioelectrochemistry 2002, $55,25-27$.

(24) Fojta, M.; Stakova, V.; Palecek, E.; Koscielniak, P.; Mitas, J. Talanta 1998, $46,155-161$

(25) Mugweru, A.; Wang, B.; Rusling, J. F. Anal. Chem. 2004, 76, 5557-5563.

(26) Dennany, L.; Forster, R. J.; White, B.; Smyth, M.; Rusling, J. F. J. Am. Chem. Soc. 2004, 126, 8835-8841.

(27) Baeumner, A. J.; Pretz, J.; Fang, S. Anal. Chem. 2004, 76, 888-894.

(28) Campbell, C. N.; Gal, D.; Cristler, N.; Banditrat, C.; Heller, A. Anal. Chem. 2002, 74, 158-162.

(29) Popovich, N. D.; Eckhardt, A. E.; Mikulecky, J. C.; Napier, M. E.; Thomas, R. S. Talanta 2002, 56, 821-828.

(30) Armistead, P. M.; Thorp, H. H. Bioconjugate Chem. 2002, 13, 172-176.

(31) Lucarelli, F.; Palchetti, I.; Marrazza, G.; Mascini, M. Talanta 2002, 56, 949957.

(32) Wang, B.; Rusling, J. F. Anal. Chem. 2003, 75, 4229-4235.

(33) Zhou, L.; Yang, J.; Estavillo, C.; Stuart, J. D.; Schenkman, J. B.; Rusling, J. F. J. Am. Chem. Soc. 2003, 125, 1431-1436.

(34) Labuda, J.; Buckova, M.; Heilerova, L.; Caniova-Ziakova, A.; Brandsteterova, E.; Mattusch, J.; Wennrich, R. Sensors 2002, 2, 1-10.

(35) Bukova, M.; Labuda, J.; Sandula, J.; Krikova, L.; I., S.; Z., D. Talanta 2002, $56,939-947$

(36) Hidaka, H.; Horikoshi, S.; Serpone, N.; Knowland, J. J. Photochem. Photobiol. A 1997, 111, 205-213.

(37) Dunford, R.; Salinaro, A.; Cai, L.; Serpone, N.; Horikoshi, S.; Hidaka, H.; Knowland, J. FEBS Lett. 1997, 418, 87-90.

(38) Liu, J.; Roussel, C.; Lagger, G.; Tacchini, P.; Girault, H. H. Anal. Chem. 2005, 77, 7687-7694.

(39) Thorp, H. H. Trends Biotechnol. 1998, 16, 117-121.

(40) Burrows, C. J.; Muller, J. G. Chem. Rev. 1998, 98, 1109-1151.

(41) Fukuzumi, S.; Miyao, H.; Ohkubo, K.; Suenobu, T. J. Phys. Chem. A 2005, 109, 3285-3294.

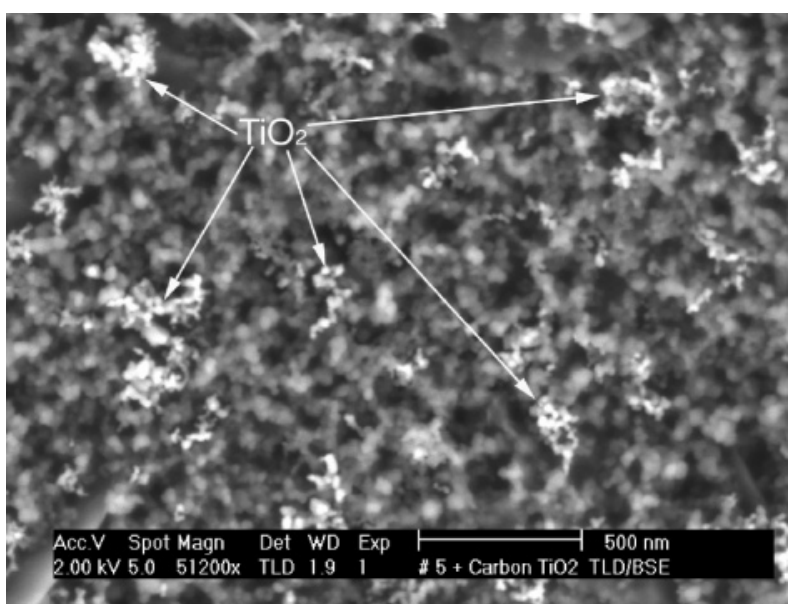

Figure 1. SEM characterization of the $\mathrm{TiO}_{2}$ modified $\mathrm{SPE}\left(\mathrm{TiO}_{2}\right.$ 5 wt \%).

voltammetry (SWV) by measuring the catalytic oxidation of Ru(bpy) $3^{2+}$ in a second solution in the absence of AOs. In this approach, the instrumentation required is limited to a potentiostat. The principle of the sensor is to measure the kinetics of the electron transfer between the oxidant $\mathrm{Ru}(\mathrm{bpy}) 3_{3}{ }^{3+}$ and $\mathrm{AOs}$, thereby inhibiting the oxidative attack on the ds-DNA. The sensors are purely electrochemical and are therefore easy of use.

\section{EXPERIMENTAL SECTION}

Materials and Instrumentation. Salmon testes ds-DNA sodium salt (Sigma) dissolved in water at a concentration of 1.7 $\mathrm{mg} / \mathrm{mL}$ was used as a stock solution. The PBS buffer was made of sodium phosphate $\left(\mathrm{Na}_{2} \mathrm{HPO}_{4}: \mathrm{NaH}_{2} \mathrm{PO}_{4}=81: 19\right.$, molar ratio) and $\mathrm{NaCl}$ dissolved in water at a final concentration of 50 and $10 \mathrm{mM}$, respectively ( $\mathrm{pH}$ 7.4). Glutathione (Sigma), gallic acid (Acros), ascorbic acid (Riedel-de Haën), uric acid (Fluka), trolox (Fluka), and bovine serum albumin (BSA; Sigma) were dissolved in PBS and used as model AOs. $\mathrm{Ru}(\mathrm{bpy})_{3} \mathrm{Cl}_{2} \cdot 6 \mathrm{H}_{2} \mathrm{O}$ was purchased from Aldrich. $\mathrm{TiO}_{2}$ nanoparticles (Degussa, P25, $21 \mathrm{~nm}$ in diameter, $50 \mathrm{~m}^{2} / \mathrm{g}$ ) were kindly provided by Dr. John Kiwi (LPIISIC-EPFL). Carbon ink (E/D 5000, Electra Polymers \& Chemicals) was mixed with $\mathrm{TiO}_{2}$ nanoparticles to fabricate $\mathrm{TiO}_{2}$ modified SPEs (the surface area of the working electrode was $10 \mathrm{~mm}^{2}$, and the thickness of the conductive layer is $\sim 40 \mu \mathrm{m})$. The surface morphology of the SPEs was characterized by scanning electron microscopy (SEM; Philips XL 30 SFEG) and is illustrated in Figure 1. An Autolab PGSTAT 30 potentiostat (Metrohm), an undivided electrochemical cell, a platinum wire counter electrode, and an $\mathrm{Ag} / \mathrm{AgCl} /$ saturated $\mathrm{KCl}$ reference electrode were used.

ds-DNA/SPE Electrodes. The $\mathrm{TiO}_{2}$ modified SPEs were immersed in a ds-DNA solution $(0.4 \mathrm{mg} / \mathrm{mL}$ in $\mathrm{pH} 3.0$ citric buffer) overnight at $4{ }^{\circ} \mathrm{C}$ for DNA adsorption. The electrodes were then dried at room temperature, washed with water, and dried again at $65{ }^{\circ} \mathrm{C}$ for $30 \mathrm{~min}$. The electrodes, denoted as ds-DNA/SPE, were then ready for use.

DNA Oxidation Damage and AO Activity Measurement. In a first step, the ds-DNA/SPE was immersed in a solution of $\mathrm{Ru}(\mathrm{bpy})_{3}{ }^{2+}(0.1,1,10 \mu \mathrm{M})$ in PBS (pH 7.4). A constant potential of $1.05 \mathrm{~V}$ versus $\mathrm{Ag} / \mathrm{AgCl}$ was applied to oxidize $\mathrm{Ru}$ (bpy) ${ }_{3}{ }^{2+}$ into $\mathrm{Ru}$ (bpy) ${ }_{3}{ }^{3+}$, which in turn oxidized ds-DNA immobilized on the SPE. Different amounts of AOs were added to the solution to study 


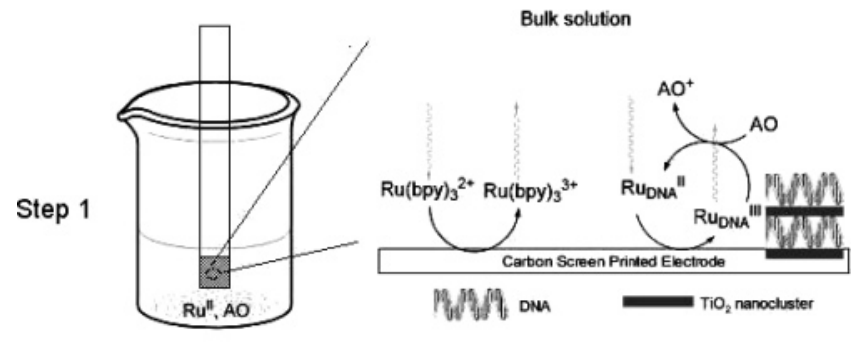

Step 2

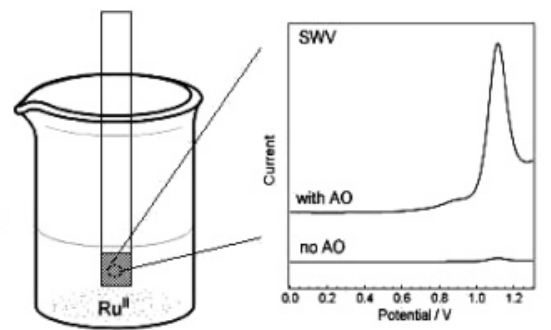

Figure 2. Schematic diagram of ds-DNA/SPE sensor principle. $R u_{D N A}^{I I}$ and $R u_{D N A}^{I I I}$ represent those redox mediators that are in the vicinity of $\mathrm{TiO}_{2}$ nanoclusters. The recycling of $\mathrm{Ru}_{\mathrm{bulk}}^{\mathrm{III}}$ by $\mathrm{AO}$ is not illustrated.

the competitive oxidation of AO in solution. In a second step, the ds-DNA/SPE electrodes were transferred in a cell containing only $\mathrm{Ru}$ (bpy) $3^{2+}$ at a low concentration $(0.1,1,10 \mu \mathrm{M})$ in PBS (pH 7.4). The catalytic oxidation current of Ru(bpy) $3^{2+}$ was measured by SWV to assay the ds-DNA oxidation damages. SWV was used with the following parameters: potential step $\Delta E_{\mathrm{s}}=5 \mathrm{mV}$, step amplitude $\Delta E_{\mathrm{sw}}=25 \mathrm{mV}$, and frequency $f=10 \mathrm{~Hz}$. The direct electrochemical oxidation of the various AOs was also studied by SWV.

Chronoamperometry of $\mathrm{Ru}(\mathrm{bpy})_{3}{ }^{2+}$ Oxidation in the Presence of AOs at SPE. Chronoamperometry was used to study the reaction rate constants between electrogenerated $\mathrm{Ru}(\mathrm{bpy})_{3}{ }^{3+}$ and $\mathrm{AOs}$ in solution. A potential of $1.05 \mathrm{~V}$ (vs $\mathrm{Ag} / \mathrm{AgCl}$ ) was applied and the current recorded as a function of time. The working electrode was a bare carbon SPE, the solutions were Ru(bpy) ${ }_{3}{ }^{2+}(1 \mu \mathrm{M})$ plus AOs in PBS (pH 7.4).

\section{RESULTS AND DISCUSSION}

The $\mathrm{TiO}_{2}$ modified SPEs have a porous surface structure with $\mathrm{TiO}_{2}$ appearing as nanoclusters, as shown in Figure 1. This porous structure facilitates ds-DNA adsorption, and the ds-DNA adsorbs mainly on the $\mathrm{TiO}_{2}$ particles because of the specific phosphate$\mathrm{TiO}_{2}$ interactions. ${ }^{42-44}$ Upon application of a potential of $1.05 \mathrm{~V}$ in a solution of $\mathrm{Ru}(\mathrm{bpy})_{3}{ }^{2+}, \mathrm{Ru}(\mathrm{bpy})_{3}{ }^{3+}$ is electrogenerated on the carbon particles and diffuses to react with the adsorbed ds-DNA, as schematically represented in Figure 2 (step 1). The $\mathrm{Ru}(\mathrm{bpy})_{3}{ }^{2+}$ formed during the ds-DNA oxidation is reelectrooxidized on the SPE, so a catalytic enhancement of the oxidation current of Ru(bpy) ${ }_{3}{ }^{2+}$ can be observed as illustrated in Figure 3 . After the indirect oxidation of ds-DNA by $\mathrm{Ru}(\mathrm{bpy})_{3}{ }^{3+}$, the electrode is transferred to another solution containing only $\mathrm{Ru}(\mathrm{bpy}){ }_{3}{ }^{2+}$, and the oxidation current catalyzed by the remaining ds-DNA is measured by SWV (Figure 2, step 2).

(42) Meier, K.-R.; Gratzel, M. ChemPhysChem 2002, 3, 371-374.

(43) Shinohara, H.; Gratzel, M.; Vlachopoulos, N.; Aizawa, M. Bioelectrochem. Bioenerg. 1991, 26, 307-320.

(44) Topoglidis, E.; Cass, A. E. G.; Gilardi, G.; Sadeghi, S.; Beaumont, N.; Durrant, J. R. Anal. Chem. 1998, 70, 5111-5113.

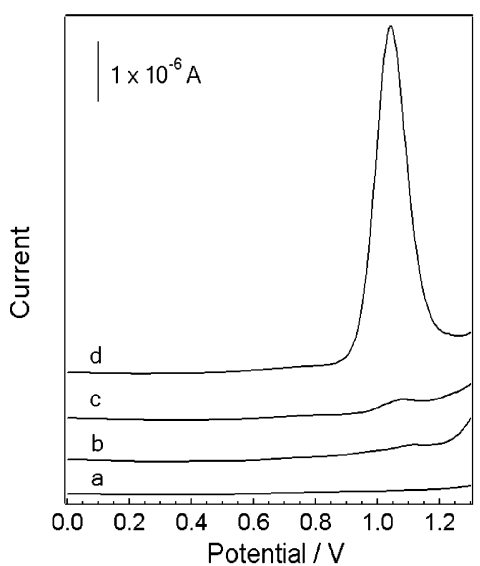

Figure 3. Square wave voltammetry for the oxidation of $\mathrm{Ru}(\mathrm{bpy})_{3}{ }^{2+}$ catalyzed by surface-adsorbed ds-DNA. (a) Blank PBS buffer on SPE; (b) $1 \mu \mathrm{M} \mathrm{Ru}(\mathrm{bpy})_{3}{ }^{2+}$ on SPE; (c) blank PBS buffer on ds-DNA/SPE; (d) $1 \mu \mathrm{M} \mathrm{Ru}(\mathrm{bpy})_{3}{ }^{2+}$ on ds-DNA/SPE.

A catalytic oxidation peak current can be observed at $\sim 1.1 \mathrm{~V}$. The peak current is directly proportional to the remaining dsDNA present on the electrode and can be considered as a direct measure of the ds-DNA damage (Figure 2, step 2). The stronger the damage, the smaller the peak current. We shall call $I_{\mathrm{t}}$ the peak current for an electrode where the ds-DNA has been oxidized during a time $t$ in the first step and $I_{0}$ is the initial value in the absence of oxidation. Figure 4 shows how the ratio $I_{t} / I_{0}$ varies with the oxidation time during the first process and illustrates how SWV can be used to probe ds-DNA damage.

To quantify the kinetic aspects of ds-DNA damage by electrontransfer reactions, we shall develop a simple kinetic model that distinguishes those $\mathrm{Ru}(\mathrm{bpy})_{3}{ }^{3+}$ generated close to a $\mathrm{TiO}_{2}$ nanoparticles called $\mathrm{R} \mathrm{u}_{\mathrm{DNA}}^{\mathrm{III}}$ from those generated too far and unable to oxidize the surface-bound ds-DNA called $\mathrm{Ru}_{\text {bulk }}^{\mathrm{III}}$. We then write

$$
\begin{gathered}
\mathrm{Ru}_{\text {bulk }}^{\mathrm{II}} \rightarrow \mathrm{Ru}_{\text {bulk }}^{\mathrm{III}} \\
\mathrm{Ru}_{\mathrm{DNA}}^{\mathrm{II}} \rightarrow \mathrm{Ru}_{\mathrm{DNA}}^{\mathrm{III}} \\
\mathrm{Ru}_{\mathrm{DNA}}^{\mathrm{III}}+\mathrm{DNA}^{\rightarrow} \rightarrow \mathrm{Ru}_{\mathrm{DNA}}^{\mathrm{II}}+\mathrm{DNA}^{+}
\end{gathered}
$$

where $\mathrm{Ru} \mathrm{DNA}_{\mathrm{DN}}^{\mathrm{II}}$ represents those redox mediators that are electrooxidized in the vicinity of $\mathrm{TiO}_{2}$ nanoparticles. $k$ is a second-order rate constant. The rate law for the production of $\left[\mathrm{Ru}_{\mathrm{DNA}}^{\mathrm{III}}\right]$ able to oxidize ds-DNA is then

$$
\begin{aligned}
\frac{\mathrm{d}\left[\mathrm{Ru}_{\mathrm{DNA}}^{\mathrm{III}}\right]}{\mathrm{d} t}=\frac{D \theta\left[\mathrm{Ru}^{\mathrm{II}}\right]^{b}}{\delta h} & - \\
& k\left[\mathrm{Ru}_{\mathrm{DNA}}^{\mathrm{III}}\right][\mathrm{DNA}]-\frac{D\left[\mathrm{Ru}_{\mathrm{DNA}}^{\mathrm{III}}\right]}{\delta h}=0
\end{aligned}
$$

where $\theta$ is the proportion of the electrode surface that contains ds-DNA at a time $t$, such that $\theta\left[\mathrm{Ru}^{\mathrm{II}}\right]^{b}$ defines the amount of "useful" $R u^{\mathrm{II}}$, namely, $\mathrm{Ru} \mathrm{u}_{\mathrm{DNA}}^{\mathrm{II}}$. In this way, $\left[\mathrm{Ru}_{\mathrm{DNA}}^{\mathrm{III}}\right]$ is the surface concentration of $\mathrm{Ru}(\mathrm{bpy})_{3}{ }^{3+}$ electrogenerated close to the $\mathrm{TiO}_{2}$ nanoparticles and $\left[\mathrm{Ru}^{\mathrm{II}}\right]^{b}$ is the bulk concentration of $\mathrm{Ru}(\mathrm{bpy})_{3}{ }^{2+}$ in solution. $D$ is the diffusion coefficient of both $\mathrm{Ru}(\mathrm{bpy})_{3}{ }^{2+}$ and 


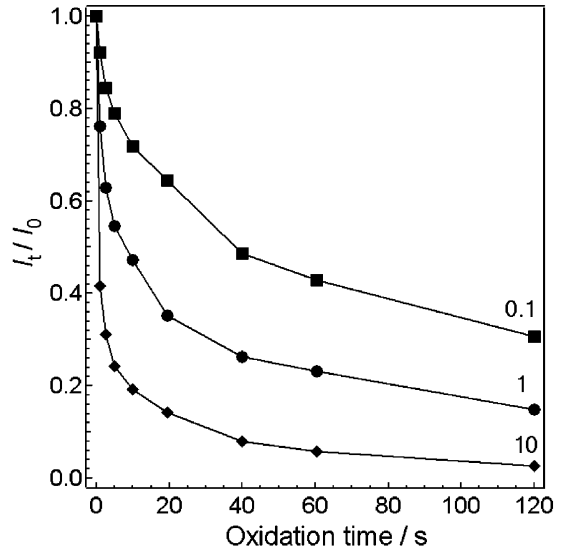

Figure 4. Peak current ratio $\left(I_{t} / l_{0}\right)$ as a function of the oxidation time during the first step for different $\mathrm{Ru}(\mathrm{bpy})_{3}{ }^{2+}$ concentrations (in $\mu \mathrm{M}$ ).

$\mathrm{Ru}$ (bpy) ${ }_{3}{ }^{3+}$ considered equal to $10^{-5} \mathrm{~cm}^{2} \mathrm{~s}^{-1} \cdot{ }^{29} \delta$ represents the diffusion layer thickness associated with the linear flux of Ru(bpy) ${ }_{3}{ }^{2+}$ from the bulk to the SPE and that of $\mathrm{Ru}$ (bpy) ${ }_{3}{ }^{3+}$ from the SPE to the bulk. $h$ represents the thickness of a thin layer at the surface of the electrode in order to avoid defining surface concentrations (in $\mathrm{mol} \mathrm{m}^{-2}$ ). In a steady-state approximation, eq 1 then yields

$$
\left[\mathrm{Ru}_{\mathrm{DNA}}^{\mathrm{III}}\right]=\frac{D \theta\left[\mathrm{Ru}^{\mathrm{II}}\right]^{b}}{k \delta h[\mathrm{DNA}]+D} \approx \theta\left[\mathrm{Ru}^{\mathrm{II}}\right]^{b}
$$

The approximation in eq 2 assumes that most of the $\mathrm{Ru} \mathrm{uNA}_{\mathrm{DN}}^{\mathrm{III}}$ generated in the vicinity of DNA diffuses away to the bulk of the solution. In other words, this assumption means that only a small fraction of the oxidized mediators generated close to a ds-DNA can be reduced to be further recycled. Since the concentration of ds-DNA is proportional to $\theta$, then the rate of consumption of dsDNA on the surface is then

$$
\begin{aligned}
& \frac{\mathrm{d}[\mathrm{DNA}]}{\mathrm{d} t}=-k\left[\mathrm{Ru}_{\mathrm{DNA}}^{\mathrm{III}}\right][\mathrm{DNA}]= \\
& \quad-k \theta^{2}[\mathrm{DNA}]_{0}\left[\mathrm{Ru}{ }^{\mathrm{II}}\right]^{b}=\frac{\mathrm{d} \theta}{\mathrm{d} t}[\mathrm{DNA}]_{0}
\end{aligned}
$$

where $[\mathrm{DNA}]_{0}$ is the initial surface concentration of DNA prior to oxidation. In this way, the following relation is obtained

$$
\theta^{-1}=1+k\left[\mathrm{Ru}^{\mathrm{II}}\right]^{b} t
$$

Since ds-DNA damage is monitored by measuring the catalytic current peak, as shown in Figures 3 and 4, we can write

$$
I_{0} / I_{\mathrm{t}}=1+k\left[\mathrm{Ru}^{\mathrm{II}}\right]^{b} t
$$

As shown in Figure 5, this simple kinetic model accounts for the experimental data. Indeed, the ratio $I_{0} / I_{\mathrm{t}}$ varies linearly with time, and the slope varies with the bulk concentration of Ru(bpy) ${ }_{3}{ }^{2+}$. From a linear fitting of eq 5 , we obtain an average $k$ value of $0.85 \times 10^{5} \mathrm{M}^{-1} \mathrm{~s}^{-1}$. This value is comparable to the value

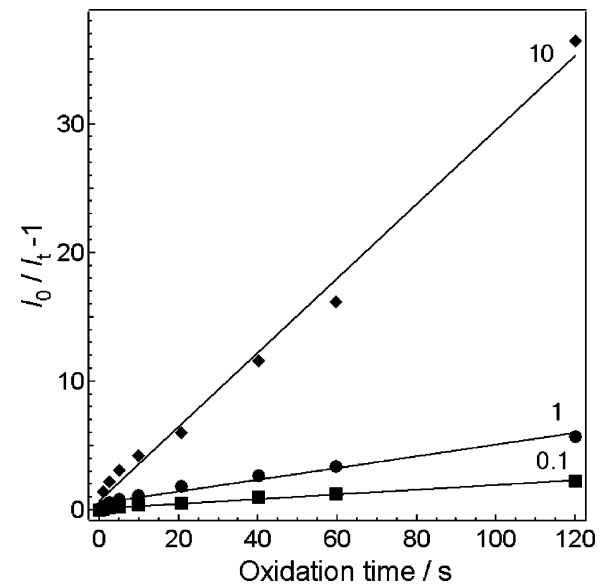

Figure 5. Plot of eq 5 as a function of the oxidation time for different $\mathrm{Ru}(\mathrm{bpy})_{3}{ }^{2+}$ concentrations (in $\mu \mathrm{M}$ ).

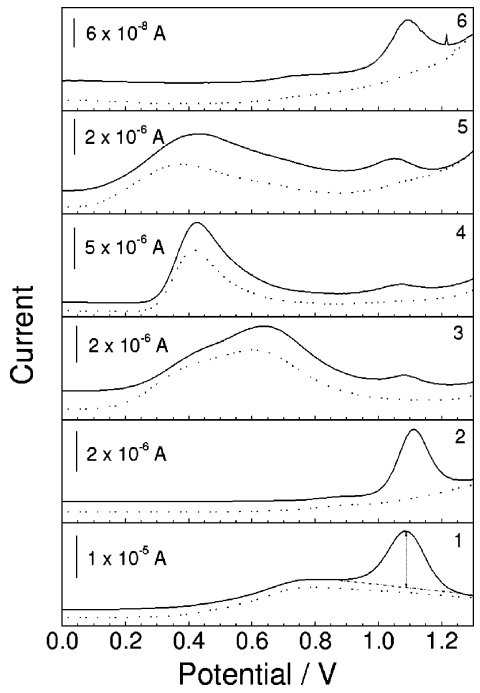

Figure 6. Square wave voltammetry for the oxidation of AOs (dot line) and $\mathrm{AOs}$ plus $\mathrm{Ru}(\mathrm{bpy}) 3^{2+}(1 \mu \mathrm{M})$ (solid line). (1) Gallic acid (1 mM); (2) glutathione (1 mM); (3) trolox (1 mM); (4) uric acid (1 mM); (5) ascorbic acid (1 mM); (6) BSA (10 mg/mL). Electrode, SPE.

of $1.3 \times 10^{5} \mathrm{M}^{-1} \mathrm{~s}^{-1}$ obtained for the oxidation of ds-DNA in solution by $\mathrm{Ru}(\mathrm{bpy})_{3}{ }^{3+}$ and measured by cyclic voltammetry at a scan rate of $50 \mathrm{mV} \mathrm{s}^{-1}$ as described in the Supporting Information.

In the presence of AOs, in the first step during the ds-DNA oxidative damaging step, the electrogenerated $\mathrm{Ru}(\mathrm{bpy}) 3_{3}{ }^{3+}$ can react also with $\mathrm{AOs}$ in solution near the electrode surface as illustrated in Figure 2 for $\mathrm{Ru}_{\mathrm{DNA}}^{\mathrm{III}}$. A set of AOs including gallic acid, glutathione, trolox, uric acid, ascorbic acid, and BSA were studied. To characterize the redox properties of these molecules on a bare carbon SPE, a SWV analysis of the electrooxidation of $\mathrm{AOs}$ and $\mathrm{AOs}$ in the presence of $\mathrm{Ru}(\mathrm{bpy})_{3}{ }^{2+}$ was performed. As illustrated in Figure 6, some AOs (trolox, uric acid, ascorbic acid, and to some extent gallic acid) are electroactive between 0 and $1 \mathrm{~V}$. In the presence of $\mathrm{Ru}(\mathrm{bpy})_{3}{ }^{2+}$, a catalytic current enhancement for the oxidation of this mediator can be observed showing that $\mathrm{Ru}(\mathrm{bpy})_{3}{ }^{3+}$ can oxidize in solution all the tested AOs. Of course for the electroactive species, their concentration at the electrode surface at $1 \mathrm{~V}$ is strongly depleted yielding a small catalytic enhancement. For those that are electroinactive on a carbon electrode (namely, glutathione, to some extent gallic acid), the enhancement is stronger. 
Considering the kinetic model developed above, the reaction scheme includes now an additional reaction

$$
\begin{gathered}
\mathrm{Ru}_{\text {bulk }}^{\mathrm{II}} \rightarrow \mathrm{Ru}_{\text {bulk }}^{\mathrm{III}} \\
\mathrm{Ru}_{\text {bulk }}^{\mathrm{III}}+\mathrm{AO} \rightarrow \mathrm{Ru}_{\text {bulk }}^{\mathrm{II}}+\mathrm{AO}^{+} \\
\mathrm{Ru}_{\mathrm{DNA}}^{\mathrm{II}} \rightarrow \mathrm{Ru}_{\mathrm{DNA}}^{\mathrm{III}} \\
\mathrm{Ru}_{\mathrm{DNA}}^{\mathrm{III}}+\mathrm{DNA} \stackrel{k}{\rightarrow} \mathrm{Ru}_{\mathrm{DNA}}^{\mathrm{II}}+\mathrm{DNA}^{+} \\
\mathrm{Ru}_{\mathrm{DNA}}^{\mathrm{III}}+\mathrm{AO} \stackrel{k_{\mathrm{AO}}}{\longrightarrow} \mathrm{Ru}_{\mathrm{DNA}}^{\mathrm{II}}+\mathrm{AO}^{+}
\end{gathered}
$$

where $k_{\mathrm{AO}}$ is the second-order kinetic rate constant of the reaction between $\mathrm{Ru} \mathrm{u}_{\mathrm{DNA}}^{\mathrm{III}}$ and $\mathrm{AO}$ in solution. This reaction is considered to take place within a catalytic layer, ${ }^{45}$ of thickness $\mu$ given by

$$
\mu=\sqrt{\frac{D}{k_{\mathrm{AO}}[\mathrm{AO}]^{b}}}
$$

Applying again the steady-state approximation to the concentration of $\mathrm{Ru}_{\mathrm{DNA}}^{\mathrm{III}}$ in the thin layer of thickness $h$, the following equation is obtained

$$
\begin{aligned}
\frac{\mathrm{d}\left[\mathrm{Ru}_{\mathrm{DNA}}^{\mathrm{III}}\right]}{\mathrm{d} t}=\frac{D \theta\left[\mathrm{Ru}^{\mathrm{II}}\right]^{b}}{\delta h}-k\left[\mathrm{Ru}_{\mathrm{DNA}}^{\mathrm{III}}\right][\mathrm{DNA}]- \\
k_{\mathrm{AO}}\left[\mathrm{Ru}_{\mathrm{DNA}}^{\mathrm{III}}\right][\mathrm{AO}]-\frac{D\left[\mathrm{Ru}_{\mathrm{DNA}}^{\mathrm{III}}\right]}{\mu h}=0
\end{aligned}
$$

Assuming that the antioxidant AO is in excess, so that the concentration of $\mathrm{AO}$ at the surface of the electrode remains equal to the bulk value $\left([\mathrm{AO}]=[\mathrm{AO}]^{b}\right)$, we then have

$$
\begin{aligned}
{\left[\mathrm{Ru}_{\mathrm{DNA}}^{\mathrm{III}}\right]=\frac{D \theta\left[\mathrm{Ru}^{\mathrm{II}}\right]^{b} \delta^{-1} h^{-1}}{k[\mathrm{DNA}]+k_{\mathrm{AO}}[\mathrm{AO}]^{b}+D \mu^{-1} h^{-1}} } & = \\
\frac{\theta\left[\mathrm{Ru}^{\mathrm{II}}\right]^{b}}{\delta\left(h \mu^{-2}+\mu^{-1}\right)} & \approx \frac{\theta \mu\left[\mathrm{Ru}^{\mathrm{II}}\right]^{b}}{\delta}
\end{aligned}
$$

and the rate of consumption of adsorbed DNA becomes

$$
\begin{aligned}
& \frac{\mathrm{d}[\mathrm{DNA}]}{\mathrm{d} t}=-k\left[\mathrm{Ru}_{\mathrm{DNA}}^{\mathrm{III}}\right][\mathrm{DNA}]= \\
& \quad-\frac{k \theta^{2} \mu[\mathrm{DNA}]_{0}\left[\mathrm{Ru}^{\mathrm{II}}\right]^{b}}{\delta}=\frac{\mathrm{d} \theta}{\mathrm{d} t}[\mathrm{DNA}]_{0}
\end{aligned}
$$

Assuming that the diffusion layer varies with $(D t)^{1 / 2}$, we get

$$
\theta^{-1}=1+\frac{k \mu\left[\mathrm{Ru}^{\mathrm{II}}\right]^{b} t}{\delta}=1+k\left[\mathrm{Ru}^{\mathrm{II}}\right]^{b} \sqrt{\frac{t}{k_{\mathrm{AO}}[\mathrm{AO}]^{b}}}
$$

As before, we express eq 10 as a function of the peak current

(45) Coury, L. A.; Oliver, B. N.; Egekeze, J. O.; Sosnoff, C. S.; Brumfield, J. C.; Buck, R. P.; Murray, R. W. Anal. Chem. 1990, 62, 452-458. obtained during the second step by SWV to obtain

$$
\frac{I_{0}}{I_{\mathrm{t}}}=1+k\left[\mathrm{Ru}^{\mathrm{II}}\right]^{b} \sqrt{\frac{t}{k_{\mathrm{AO}}[\mathrm{AO}]^{b}}}
$$

As shown in Figure 7, the experiments corroborate reasonably well the kinetic model. High concentrations of trolox $(0.5 \mathrm{mM})$, uric acid $(1 \mathrm{mM})$, and ascorbic acid $(1 \mathrm{mM})$ were used to ensure that despite their direct electrooxidation on the electrode surface an excess amount of AO molecules are available to react with Ru(bpy) ${ }_{3}{ }^{3+}$. The kinetic constants $\left(k_{\mathrm{AO}}\right)$ can be obtained from this model, they are $6.2 \times 10^{3}, 1.43 \times 10^{3}, 166,67,52$, and $210 \mathrm{M}^{-1}$ $\mathrm{s}^{-1}$ for gallic acid, glutathione, trolox, uric acid, ascorbic acid, and $\mathrm{BSA}$, respectively.

For those molecules that are electroinactive on the electrode, $k_{\mathrm{AO}}$ values can be obtained directly by chronoamperometry considering a simple EC mechanism. ${ }^{46}$ The catalytic oxidation current of $\mathrm{Ru}(\mathrm{bpy})_{3}{ }^{2+}$ in the presence of AOs, $I_{\text {Cottrell }}$, is related to the current transient $I_{\mathrm{d}}$ for the oxidation current of Ru(bpy) ${ }_{3}{ }^{2+}$ alone by

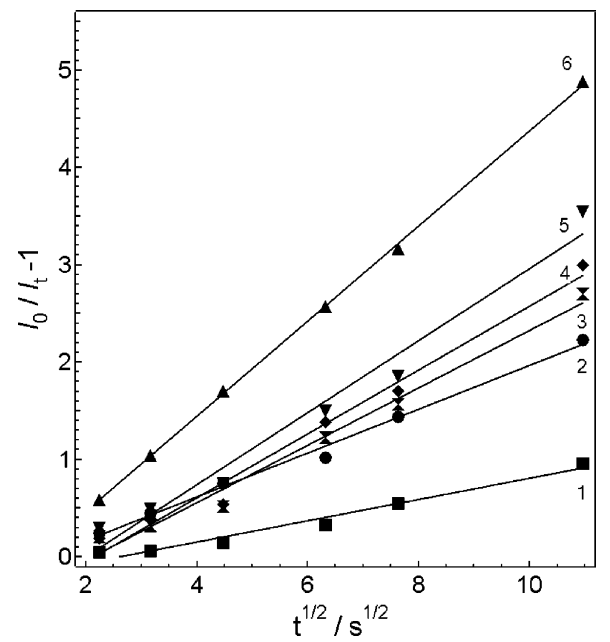

Figure 7. Plot of eq 11. (1) Gallic acid $(0.1 \mathrm{mM})$; (2) glutathione (0.1 mM); (3) trolox (0.5 mM); (4) uric acid (1 mM); (5) ascorbic acid (1 mM); (6) BSA (10 mg/mL). Ru(bpy $)_{3}{ }^{2+}(1 \mu \mathrm{M})$; electrode, ds-DNA/ SPE.

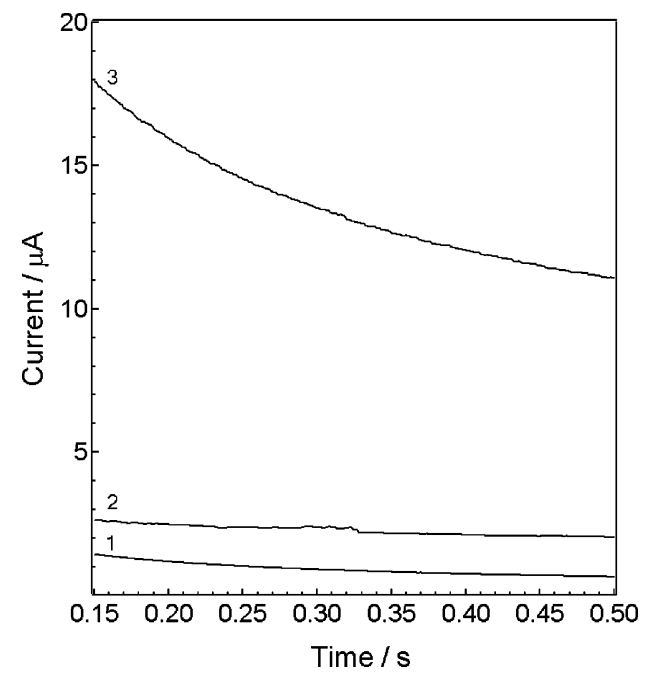

Figure 8. $I_{\text {Cottrell }}$ for the oxidation of $\mathrm{Ru}(\mathrm{bpy})_{3}{ }^{2+}$ in the presence of glutathione (2), gallic acid (3) and $/ d$ for the simple oxidation of Ru$\left(\right.$ bpy) ${ }_{3}^{2+} 1 \mu \mathrm{M}(1)$ on a bare screen-printed carbon electrode. 
Table 1. Comparison of Antioxidant Capacities Obtained from Different Methods

\begin{tabular}{|c|c|c|c|}
\hline \multirow[b]{3}{*}{$\mathrm{AOs}$} & \multicolumn{3}{|c|}{ antioxidant capacities } \\
\hline & \multirow[b]{2}{*}{$\begin{array}{c}\text { apparent } k_{\mathrm{AO}}{ }^{a} \\
\left(\mu \mathrm{A} \mathrm{mM}^{-1}\right)\end{array}$} & \multicolumn{2}{|c|}{$\begin{array}{c}\mathrm{Ru}(\mathrm{bpy})_{3}{ }^{3+} \text { oxidation } \\
k_{\mathrm{AO}}\left(\mathrm{M}^{-1} \mathrm{~s}^{-1}\right)\end{array}$} \\
\hline & & at ds-DNA/SPE ${ }^{b}$ & $\begin{array}{c}\text { chrono- } \\
\text { amperometry }^{c}\end{array}$ \\
\hline gallic acid & 26.5 & $6.2 \times 10^{3}$ & $4.3 \times 10^{3}$ \\
\hline glutathione & 1.65 & $1.4 \times 10^{3}$ & $1.2 \times 10^{3}$ \\
\hline trolox & & 166 & \\
\hline uric acid & & 67 & \\
\hline ascorbic acid & & 52 & \\
\hline BSA & & 210 & 200 \\
\hline
\end{tabular}

${ }^{a}$ Apparent kinetic constants of reactions between $\mathrm{AOs}$ and $\mathrm{OH}^{*}$ radicals. ${ }^{38}{ }^{b}$ According to eq $11 .{ }^{c}$ According to eq 12 .

$$
I_{\text {Cottrell }} / I_{\mathrm{d}}=\pi^{1 / 2} \lambda^{1 / 2}
$$

where $\lambda$ is the kinetic parameter defined by

$$
\lambda=k_{\mathrm{AO}}[\mathrm{AO}]^{b} t
$$

Shown in Figure 8 are the current responses in the presence of AOs. The slope $\left(\pi k_{\mathrm{AO}}[\mathrm{AO}]^{b}\right)$ of the plot $\left(I_{\text {Cottrell }} / I_{\mathrm{d}}\right)^{2}$ versus $t$ in the time domain between 0.15 and $0.5 \mathrm{~s}$ yields $k_{\mathrm{AO}}$ values of $4.3 \times$ $10^{3} \mathrm{M}^{-1} \mathrm{~s}^{-1}$ for gallic acid, $1.2 \times 10^{3} \mathrm{M}^{-1} \mathrm{~s}^{-1}$ for glutathione, and $200 \mathrm{M}^{-1} \mathrm{~s}^{-1}$ for BSA. These $k_{\mathrm{AO}}$ values correlate well with those obtained from eq 11 . These chronoamperometric data therefore validate the ds-DNA SPE electrode approach developed above for any types of molecules.

Table 1 presents a summary of $k_{\mathrm{AO}}$ values or antioxidant capacities obtained from photocatalytic reactions at ds-DNA/ $\left(\mathrm{TiO}_{2}\right)_{3} / \mathrm{ITO}^{38} \mathrm{Ru}(\mathrm{bpy})_{3}{ }^{3+}$ oxidation at ds-DNA/SPE, and by chronoamperometry.

(46) Bard, A. J.; Faulkner, L. R. Electrochemical Methods: Fundamentals and Applications; John Wiley and Sons: New York, 1980.
CONCLUSIONS

We have demonstrated the possibility to study the redox antioxidant properties of chemical compounds using an electrochemical-based DNA modified SPE (ds-DNA/SPE). Electrogenerated $\mathrm{Ru}$ (bpy) ${ }_{3}{ }^{3+}$ was used as a ds-DNA redox oxidant in the absence and presence of antioxidant molecules. The ds-DNA oxidation damage is monitored by measuring the catalytic oxidation of $\mathrm{Ru}$ (bpy) ${ }_{3}{ }^{2+}$. A simple kinetic model was proposed to quantify the rate constants between $\mathrm{Ru}(\mathrm{bpy})_{3}{ }^{3+}$ and adsorbed ds-DNA and between $\mathrm{Ru}(\mathrm{bpy})_{3}{ }^{3+}$ and $\mathrm{AOs}$ in aqueous solutions. In the former case, the rate constants measured are similar to those measured by cyclic voltammetry between $\mathrm{Ru}(\mathrm{bpy})_{3}{ }^{3+}$ and ds-DNA in solution. In the latter case, the values obtained correlate well with those obtained by chronoamperometry for the non electroactive molecules. It is important to stress that to assay an antioxidant capacity of a molecule, it is necessary to carry out kinetics studies. The present approaches are based on competition reactions and on comparing the rate of oxidation of adsorbed ds-DNA and the rate of oxidation in the bulk of an antioxidant species. The present study complements the previous one ${ }^{38}$ based on the photocatalytic generation of $\mathrm{OH}^{\bullet}$ radicals and the electrochemical detection of DNA damage using a redox intercalant.

\section{ACKNOWLEDGMENT}

Fabienne Bobard and Prof. P. Buffat (Centre Interdisciplinaire de Microscopie Electronique, EPFL) are acknowledged for SEM studies. This project is supported by Commission for Technology and Innovation of Switzerland (CTI-6425.1).

\section{SUPPORTING INFORMATION AVAILABLE}

Estimation of the second-order rate constant of the direct oxidation of ds-DNA in solution by $\mathrm{Ru}(\mathrm{bpy}) 3^{3+}$ on the basis of cyclic voltammetric measurements and simulations. This material is available free of charge via the Internet at at http://pubs.acs.org.

Received for review May 11, 2006. Accepted July 25, 2006.

AC0608624 